\title{
An Experimental and Theoretical Conformational Study of a Series of Substituted 3-cyclohexyl-2-phenyl-1,3-thiazolidin-4-ones
}

\author{
Kevin Cannon ${ }^{1}$, Linda Mascavage ${ }^{2}$, Kurt Kistler $^{3}$, John Tierney ${ }^{3}$, Hemant Yennawar ${ }^{4}$ \& Anthony Lagalante ${ }^{5}$ \\ ${ }^{1}$ Department of Chemistry, Pennsylvania State University, Abington Campus, Abington, USA \\ ${ }^{2}$ Department of Chemistry, Arcadia University, Glenside, USA \\ ${ }^{3}$ Department of Chemistry, Pennsylvania State University, Brandywine Campus, Media, USA \\ ${ }^{4}$ Departments of Biochemistry \& Molecular Biology and Chemistry, Pennsylvania State University, University \\ Park, USA \\ ${ }^{5}$ Department of Chemistry, Villanova University, Villanova, USA \\ Correspondence: John Tierney, Department of Chemistry, Pennsylvania State University, Brandywine Campus, \\ Media, PA 19063, USA. Tel: 1-610-892-1417. E-mail: jxt4@psu.edu
}

Received: April 19, 2013 Accepted: May 31, 2013 Online Published: July 12, 2013

doi:10.5539/ijc.v5n3p46 URL: http://dx.doi.org/10.5539/ijc.v5n3p46

\begin{abstract}
A series of novel 3-cyclohexyl-2-phenyl-1,3-thiazolidin-4-one derivatives with substituents on the 2-phenyl ring were synthesized, and a study of their solid state and solution conformations was effected. In solution the thiazolidin-4-one ring preferred the $\mathrm{C} 2$ phenyl in a pseudo-equatorial orientation and the solid state indicated a preference for the $\mathrm{C} 2$ phenyl being in a pseudo-axial orientation. Less robust substituent chemical shift (SCS) correlations utilizing ${ }^{13} \mathrm{C}$ NMR were observed in this instance than in prior studies. Molecular modeling studies using Møller-Plessett second-order perturbation theory (MP2) indicate that the thiazolidinone ring and cyclohexyl ring conformations exhibit a global minimum consistent with the solution studies.
\end{abstract}

Keywords: thiazolidin-4-ones, ${ }^{1} \mathrm{H}$ NMR, ${ }^{13} \mathrm{C}$ NMR, substituent effects, MP2 calculations

\section{Introduction}

Studies of the biological activity of many substituted thiazolidinone systems have been undertaken, and a diverse series of activities has been reported with this heterocyclic system (Vazzana, Terranova, Maittioli, \& Sparatore, 2004; Barreca et al., 2001; Ravichandran et al., 2008).

Previously, six series of thiazolidinones, shown in Figure 1(Series 1-6), had been studied (Woolston et al., 1992; Woolston et al., 1993; Tierney, Houghton, et al., 1996; Tierney, Issac, et al., 1996; Tierney, Sheridan, et al., 1996). The sensitivity of electron density shifts at the methine proton $\left(\mathrm{H}_{\mathrm{x}}\right)$ at $\mathrm{C} 2$ and the methylene protons $\left(\mathrm{H}_{\mathrm{a}}\right.$ and $\left.\mathrm{H}_{\mathrm{b}}\right)$ at $\mathrm{C} 5$ related to substituents on each phenyl ring (Series 1 and 2) have been determined from ${ }^{1} \mathrm{H}$ NMR data. Hammett values and Swain Lupton $r$ (resonance) and $f$ (field or inductive) coefficients have been used as indicators. Two of the studies used different arrays of phenyl substituents with comparable results (Woolston et al., 1992; Tierney et al., 1996). In addition, similar studies had been carried out utilizing ${ }^{13} \mathrm{C}$ chemical shift data at $\mathrm{C} 2, \mathrm{C} 4$ and C5, from the substituents attached to the phenyl or benzyl moieties in Series 1 through 6, Figure 1. A prior focus of study for compounds in Series 1, 2 and 5, Figure 1, had been on the conformation of the thiazolidin-4-one ring in both solid state from X-ray analysis (Hickel et al., 1983; Tierney et al., 2005), and in solution from NMR data (Woolston et al., 1992; Woolston et al., 1993; Tierney, Houghton, et al., 1996). 
<smiles>[R][C@H]1S[C@@H]([2H])C(=O)N1[R]</smiles>

Series 1: $R=$ phenyl, $R^{\prime}=m$ - and $p$-substituted phenyl

Series 2: $R=m$ - and $p$-substituted phenyl, $R^{\prime}=$ phenyl

Series 3: $R=$ phenyl, $R^{\prime}=m$ - and $p$-substituted benzyl

Series 4: $R=m$ - and $p$-substituted benzyl, $R^{\prime}=$ phenyl

Series 5: $R=m$ - and $p$-substituted phenyl, $R^{\prime}=2$-pyridyl

Series 6: $R=$ trichloromethyl, $R^{\prime}=m$ - and $p$-substituted phenyl

Series 7: $R=m$ - and $p$-substituted phenyl, $\mathbf{R}^{\prime}=$ cyclohexyl

Figure 1. All series of substituted thiazolidinones studied to date. The meta and para substituents in all series are consistently: $p$ - $\mathrm{NO}_{2} ; m-\mathrm{NO}_{2} ; p$-F; $m$-F; $p$ - $\mathrm{Cl} ; m-\mathrm{Cl} ; p$ - $\mathrm{Br} ; m-\mathrm{Br} ; \mathrm{H}, p-\mathrm{Me} ; m-\mathrm{Me} ; p-\mathrm{MeO} ; m-\mathrm{MeO}$

Solid state conformational studies (Hickel et al., 1983; Tierney et al., 2005) of diaryl compounds (Series 1, 2 and 5) showed that their conformation is different in the solid state from that in solution. Using X-ray data, Woolston concluded that conformer A (Figure 2) is the preferred solid state conformer, with the C2 aryl group (R) pseudo-axial and conformer B (Figure 2) is the preferred conformer in solution (Woolston et al., 1992; Hickel et al., 1983). The thiazolidin-4-one ring has a chiral center at $\mathrm{C} 2$ ensuring that the methylene protons at $\mathrm{C} 5$ are nonequivalent, leading to an ABX splitting pattern in ${ }^{1} \mathrm{H}$ NMR. The conformational assignments were made based on NMR NOE experiments. Additional ${ }^{1} \mathrm{H}$ NMR dataalso links the methine proton, $\mathrm{H}_{\mathrm{x}}$, coupling to the lower field trans methylene proton $\mathrm{H}_{\mathrm{b}}$ for 2,3-diphenyl-1,3-thiazolidin-4-one.

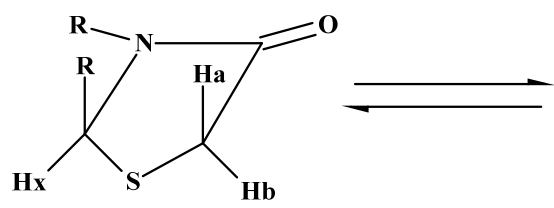

A

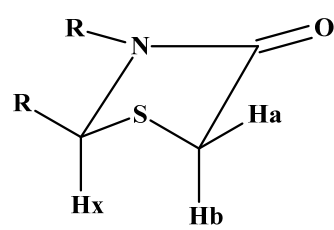

B

Figure 2. Thiazolidin-4-one ring conformers

In this present study (Figure 1, Series 7) NMR data and X-ray data for the same compound were utilized rather than comparing compounds that have the same heterocyclic nucleus but different aryl moieties at $\mathrm{C} 2$ and N3, as in the case of the Woolston study (Woolston et al., 1993; Hickel et al., 1983). In addition, ab initio molecular modeling information is introduced to enhance the understanding of the solution state conformers in the $\mathrm{C} 2$ phenyl N3 cyclohexyl series of substituted thiazolidin-4-ones.

\section{Results and Discussion}

\subsection{General}

The series of compounds described here is shown in Figure 1, Series 7. One major difference compared to observations made in previous studies utilizing ${ }^{13} \mathrm{C}$ NMR data was the weaker substituent chemical shift correlations at the C2 site, Figure 3 (Woolston et al., 1992; Woolston et al., 1993; Tierney, Houghton, et al., 1996; Tierney, Issac, et al., 1996; Tierney, Sheridan, et al., 1996). At first sight it appears that very good correlation is lacking, but on closer inspection one sees that the $p$-methoxy and the $m$-nitro substituents are the most divergent from the trend line. In previous studies (Tierney et al., 2005; Tierney et al., 2008) of additivity effects in the predictions of NMR chemical shift values for substituted diphenylthiazolidin-4-ones it has been shown that the meta-nitro compounds have the least predictable chemical shifts for these systems. However, this is the first instance where divergence with the $p$-methoxy group has manifested itself when investigating Hammett correlations. Johnson has previously addressed the situations in which strongly electron donating groups, in particular the $p$-methoxy group, show significant deviations when using Hammett $\sigma, \sigma^{+}$or $\sigma^{-}$correlations (Johnson, 1978). One explanation for this deviation is that the substituted phenyl ring is twisted out of full conjugation with the site being observed. This appears to be the case here, but why it does not similarly affect the 
other substituents in this system is still not clear. If the $p$-methoxy and the $m$-nitro substituents are excluded from the observations the results can be seen in Table 1. Correlations were improved if the meta substituted compounds are removed from consideration in Series 1-6, Figure 1, so this improved outcome is not surprising. As in all the prior studies (Series 1-6, Figure 1) the $\rho$ value is negative showing that $\mathrm{C} 2$ prefers a positive charge density. Interestingly, where reasonable correlations were also seen for the ${ }^{13} \mathrm{C}$ chemical shift data versus Hammett $\sigma$ values at C4 and C5 for Series 1-6, Figure 1, this was not the case here. The limited ability to see the effective transmission of substituent effects to more distant sites is probably in concert with the slight twisting of the phenyl group at $\mathrm{C} 2$ in the thiazolidinone ring as proposed by Johnson (Johnson, 1978).

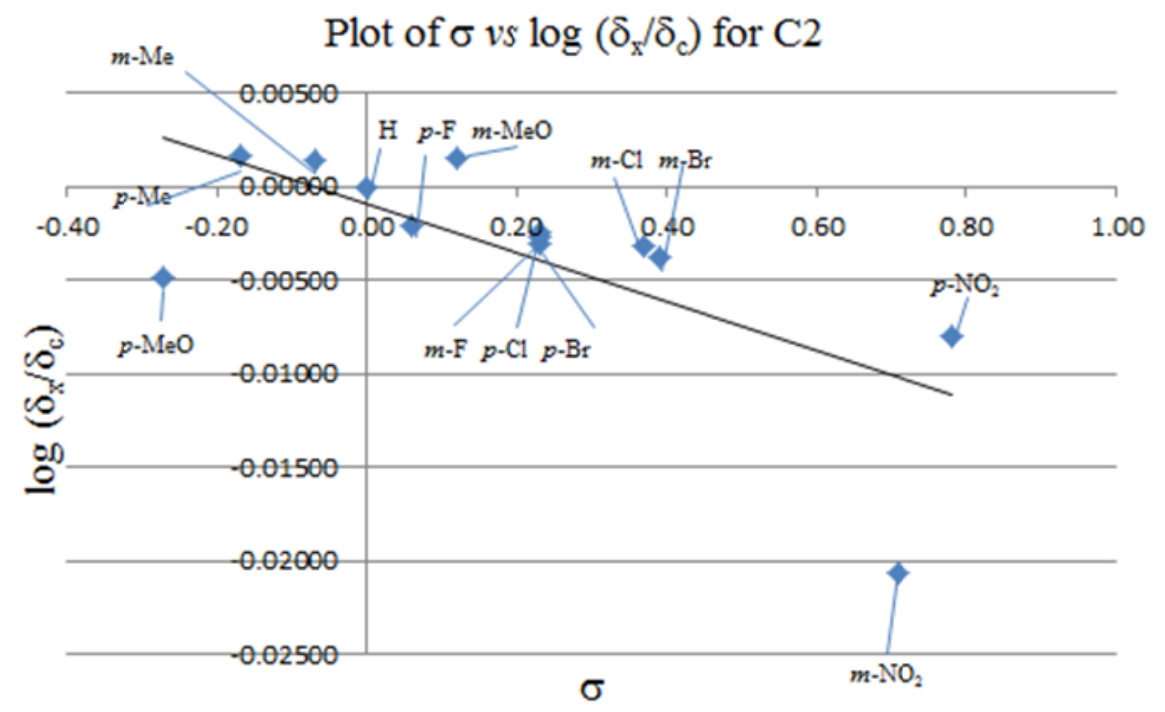

Figure 3. Plot of Hammett versus all ${ }^{13} \mathrm{C}$ values for the $\mathrm{C} 2$ carbon in the thiazolidin-4-one ring

Table 1. The equations for correlations of Hammett with substituent chemical shifts

\begin{tabular}{lll}
\hline Equation & $\mathbf{R}^{2}$ & Comment \\
\hline $\mathrm{C} 2$ & & \\
$\mathrm{y}=-0.0131 \mathrm{x}-0.0009$ & 0.488 & all substituents, $\mathrm{n}=13$ \\
$\mathrm{y}=-0.0104 \mathrm{x}-0.0002$ & 0.870 & minus $m-\mathrm{NO}_{2}$ and $p-\mathrm{MeO}, \mathrm{n}=11$ \\
$\mathrm{y}=-0.0099 \mathrm{x}-0.0004$ & 0.971 & all para substituted except $p-\mathrm{MeO}, \mathrm{n}=6$ \\
\hline
\end{tabular}

\subsection{Solid State Study}

It can be seen from the ORTEP model (Figure 4) that the phenyl ring and the cyclohexyl ring positions are best described by conformer $\mathrm{A}$ in Figure 2. This observation is in concert with the X-ray structure for 2-(2'-methylphenyl)-3-(2"-pyridyl)-1,3-thiazolidin-4-one (Hickel et al., 1983) and for the 2,3-diphenylthiazolidin-4-one ligand coordinated to triphenyltin chloride (Smith et al., 1996). Even though the 2,3-diphenyl-thiazolidin-4-one was coordinated to the tin through the carbonyl oxygen, the heterocyclic ring preferred having the two phenyl groups with one pseudo axial orientation. Woolston attributed the previously observed difference between the solid state conformation from Hickel's X-ray data and the solution conformation to be due to the presence of the methyl group in 2-(2'-methyl-phenyl)-3-(2"-pyridyl)-1,3-thiazolidin-4-one, but this cannot be the case (Woolston et al., 1992; Hickel et al., 1983). It is also evident that the favored solid state conformation shown by Hickel's datais the same when the groups at $\mathrm{C} 2$ and $\mathrm{N} 3$ are replaced by a phenyl and a cyclohexyl group. Clearly the packing forces 
required for crystalline systems are different to those observed in the solution, liquid, or gaseous states. By having the rings assume these orientations, this adapted conformation appears to be the most energetically favorable for crystal packing regardless of substituents in the rings or the type of ring.

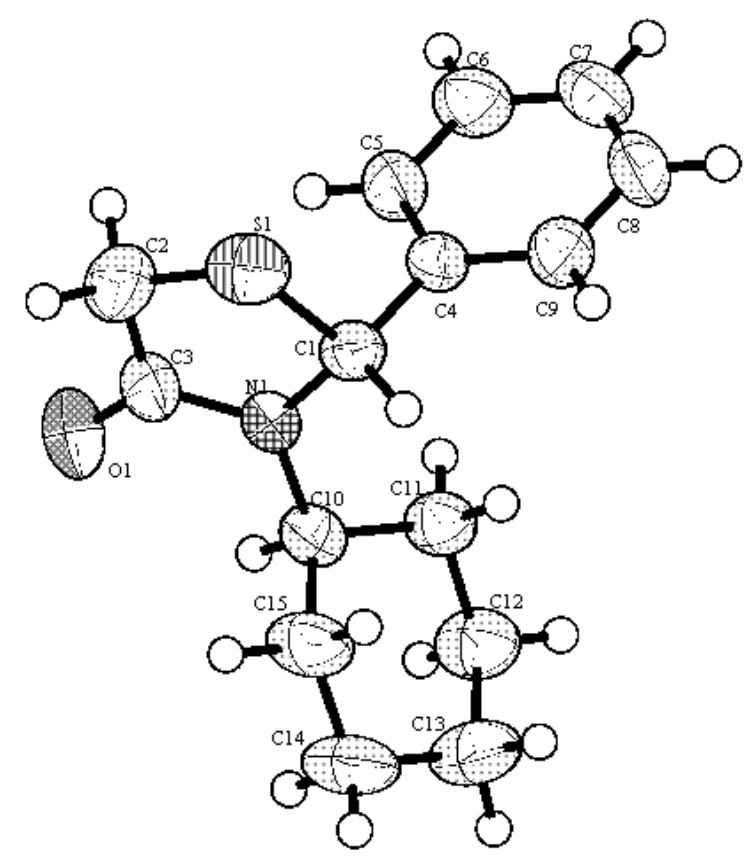

Figure 4. Note: the numeric assignments for atoms in the ORTEP model do not concur with IUPAC nomenclature

\subsection{Solution Study}

In the prior studies on 2,3-diphenylthiazolidin-4-ones, the solution NMR studies focused solely on the conformation of the thiazolidinone ring (Woolston et al., 1992; Woolston et al., 1993; Tierney, Houghton, et al., 1996; Tierney, Issac, et al., 1996; Tierney, Sheridan, et al., 1996). However, in this instance there are two rings whose conformers can change simultaneously, the thiazolidinone and cyclohexyl rings. In the previous studies, the presence of the aryl moieties at $\mathrm{C} 2$ and $\mathrm{N} 3$ produced a more rigid environment due to the array of $\mathrm{sp}^{2}$ hybridized atoms in the phenyl rings. There is an increase in the number of degrees of freedom by the introduction of a cyclohexyl group at N3. This ring can flip from one chair conformation to the other. In addition there is also the possibility that the cyclohexyl ring can point towards or away from the carbonyl group. It was envisaged, in advance of the study, that a number of possible conformational outcomes would be possible, and these are shown in Figure 5.To simplify the calculations an initial decision was made to exclude a pyramidal nitrogen geometry, focusing only on a planar nitrogen for the amide in the heterocyclic ring. A planar nitrogen had already been proposed as the preferred geometry in prior studies series, but it should be noted that the X-ray analysis does show a slightly nonplanar configuration (Woolston et al., 1992; Woolston et al., 1993; Tierney, Houghton, et al., 1996).

The sulfur atom has the possibility of being puckered up or down with the respect to the rest of the thiazolidinone ring. The phenyl ring can either take up a pseudo axial or pseudo equatorial position on the thiazolidinone ring. In addition, the cyclohexyl ring itself can show either an axial or equatorial geometry at the amide nitrogen of the thiazolidinone ring. Additionally, as already mentioned, the cyclohexyl ring can point either towards or away from the carbonyl oxygen. Because of the near planarity around the amide nitrogen, the cyclohexyl ring is orthogonal to the plane of the thiazolidinone ring. Those conformers with the sulfur atom puckered down in the thiazolidinone ring are shown in structures $5 \mathrm{a}, 5 \mathrm{~b}, 5 \mathrm{e}$, and $5 \mathrm{f}$, and those with the sulfur atom puckered up are shown in structures $5 \mathrm{c}, 5 \mathrm{~d}, 5 \mathrm{~g}$, and $5 \mathrm{~h}$. The axial and equatorial conformations exhibiting the cyclohexyl ring pointing towards the carbonyl oxygen of the heterocyclic ring are shown in structures 5a through $5 \mathrm{~d}$, and structures $5 \mathrm{e}$ through $5 \mathrm{~h}$ show the cyclohexyl ring pointing away from the carbonyl oxygen. 
The ABX coupling pattern observed in the ${ }^{1} \mathrm{H}$ NMR between the methine proton, $\mathrm{H}_{\mathrm{x}}$, and the methylene protons are in concert with the previously reported NMR studies for thiazolidinone ring conformations in solution (Woolston et al., 1992; Woolston et al., 1993; Tierney, Houghton, et al., 1996). The long range coupling between the methine proton $\mathrm{H}_{\mathrm{x}}$ at $\mathrm{C} 2$ and the trans lower field methylene proton $\mathrm{H}_{\mathrm{b}}$, at $\mathrm{C} 5$ can be seen in Figure 6 . The reason that $\mathrm{W}$-plane coupling is not seen in this system is because the $\mathrm{C} 2-\mathrm{S}-\mathrm{C} 5$ atoms in the thiazolidinone ring are not coplanar. This is evident in the solid state analysis and the structures generated in the MP2 calculations.

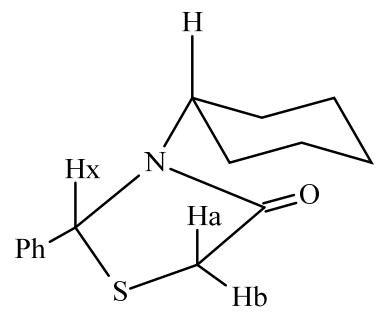

a<smiles>O=C1CCCCCC1([PH])c1ccccc1</smiles>

c

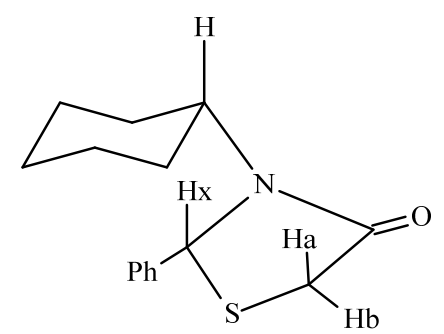

e

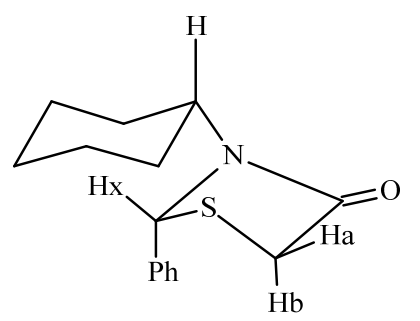

g<smiles>[2H]C1(c2ccccc2)SC([In])C(=O)N1C1CCCCC1</smiles>

b

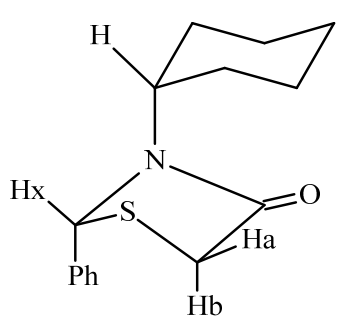

d<smiles></smiles>

f

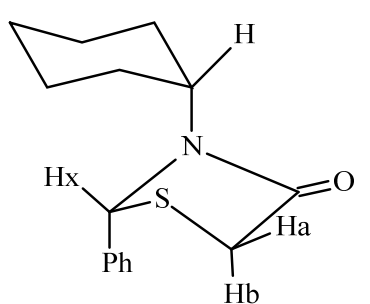

h

Figure 5. Possible conformations of the thiazolidinone cyclohexane rings 


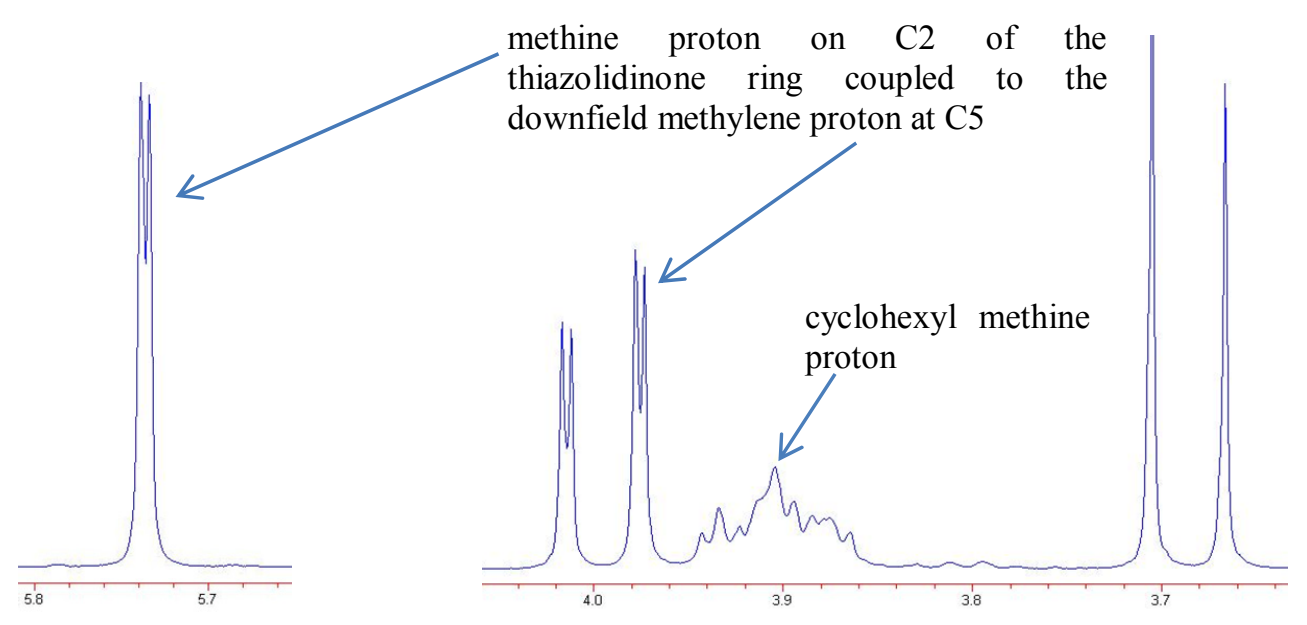

Figure 6. ${ }^{1} \mathrm{H}$ NMR spectra of the methine and methylene regions for

3-cyclohexyl-2-phenyl-1,3-thiazolidin-4-one

\subsection{Molecular Modeling Study}

As previously discussed in this report, the amide ring nitrogen has been shown to be either planar or close to planar geometry. Nonetheless, in order to more fully explore the ground state potential surface for possible local and global minima, geometry optimizations using Møller-Plessett second-order perturbation theory (MP2) and the correlation-consistent basis set cc-pVDZ (Dunning, 1989) were carried out starting with each of the eight conformers given in Figure 5, using the GAMESS suite of quantum programs (Frisch et al., 2010). Molecular visualizations were done with MOLDEN.

Two different local minima were located at this level of theory. Their optimized structures are shown in Figure 7. One, which is slightly more stable at this level of theory, corresponds to the configuration with a pseudo equatorial phenyl, oriented up, sulfur puckered up, the cyclohexyl ring oriented orthogonal to the thiazolidinone ring with the $\mathrm{C} 1$ hydrogen of the cyclohexyl ring pointing away from the carbonyl, and the cyclohexyl ring in a chair conformation its $\mathrm{C} 3$ and $\mathrm{C} 5$ atoms pointing away from the carbonyl. The amide nitrogen is slightly pyramidalized up by about $10.5^{\circ}$. Its MP2 energy with this basis set is -1108.52628 Hartree. This minimum also corresponds to the energetically degenerate enantiomeric conformer having a pseudo equatorial phenyl, oriented down, sulfur puckered down, the cyclohexyl is the same as above, and the amide nitrogen pyramidalized slightly down. In terms of the phenyl and sulfur orientation this is qualitatively commensurate with structure $7 \mathrm{a}$ (and is equivalent to $5 \mathrm{a}$ ).

The second minimum is for Figure $7 \mathrm{~d}$ (and is equivalent to 5d), and its MP2 energy using this basis set is -1108.51718 Hartree. This minimum corresponds to a geometry having a pseudo axial phenyl pointing down, the sulfur puckered up, the chair conformation of the cyclohexyl ring oriented orthogonal to the thiazolidinone ring with its $\mathrm{C} 1-\mathrm{H}$ pointing away from the carbonyl, but now with $\mathrm{C} 3$ and $\mathrm{C} 5$ pointing towards the carbonyl.

The difference in energies of these two minima is 0.00910 Hartree, or $5.69 \mathrm{kcal} / \mathrm{mol}$. If we approximate this energy difference to be the free-energy difference, it is large enough to predict $7 \mathrm{a}$ as the global minimum, which supports the experimental data previously reported for other similarly disubstituted thiazolidinones (Tierney, Houghton, et al., 1996). Interestingly, if the chair conformation of the cyclohexyl ring in structure $7 \mathrm{~d}$ is inverted, that is, changed to a chair conformer now oriented orthogonal to the ring with $\mathrm{C} 3$ and $\mathrm{C} 5$ pointing away from the carbonyl, this new structure with the inverted cyclohexyl ring is allowed to optimize at the MP2/cc-pVDZ level to the other minimum, 7a, which is located without any energetic barriers other than that required to overcome the inversion of the cyclohexyl's chair conformation. Likewise, if the cyclohexyl ring of the optimized structure $7 \mathrm{a}$ is inverted to a chair conformer with $\mathrm{C} 3$ and $\mathrm{C} 5$ oriented towards the carbonyl, further optimization at this level of theory locates the local minimum corresponding to structure $7 \mathrm{~d}$ without further energetic barriers. At this time a theoretical value for the barrier of this cyclohexyl inversion is not known, but if it is assumed that this inversion of the cyclohexyl ring between these two chair orientations occurs at room temperature, and the system is reaches equilibrium between structure $7 \mathrm{a}$ and $7 \mathrm{~d}$, the energy difference would still place $7 \mathrm{a}$ as the dominant conformer in solution, and 7 dpresent as only a minor conformer. 


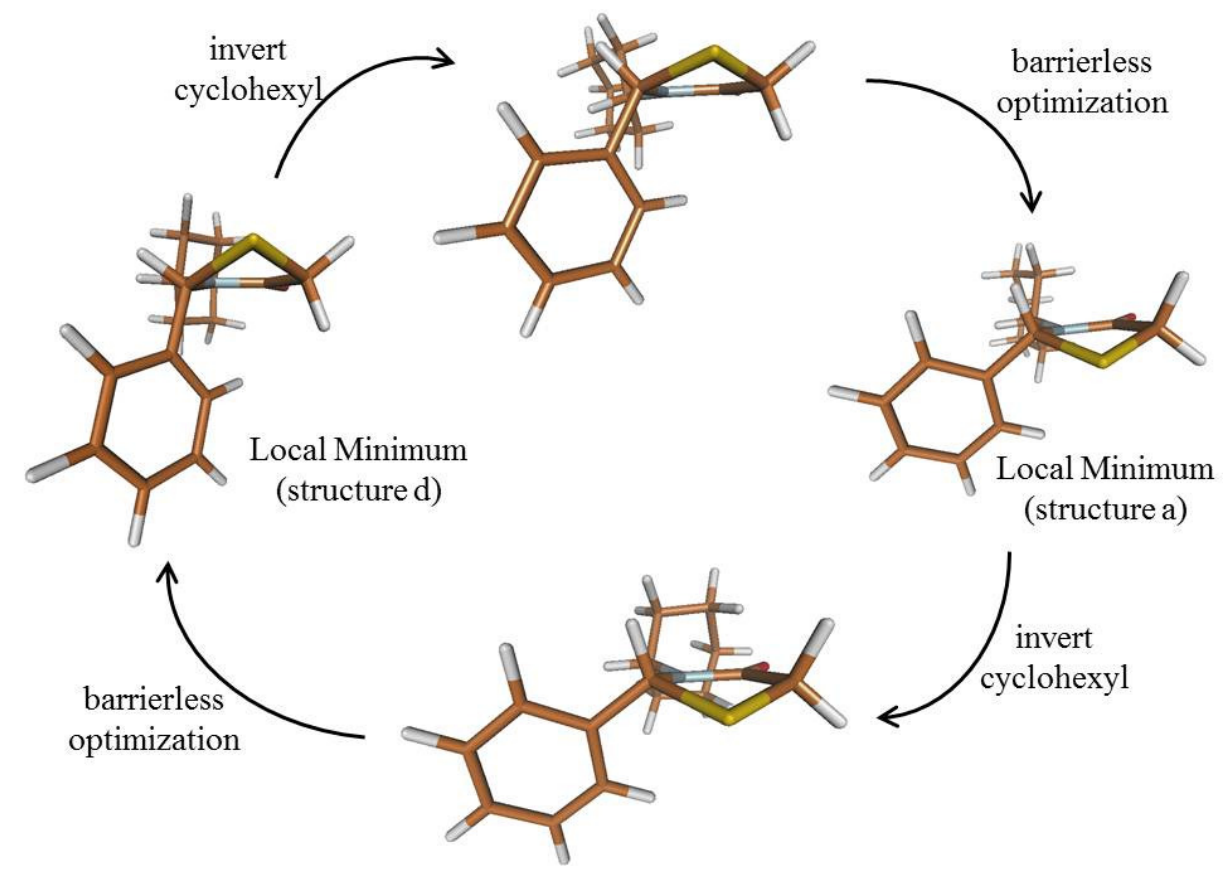

Figure 7. The two local minima are shown, corresponding to structures $5 \mathrm{a}$ and $5 \mathrm{~d}$ in Figure 5. Inverting the cyclohexyl chair conformation, as described in the text, of one minimum, followed by MP 2 optimization, leads without barrier to the other minimum

\section{Conclusion}

The results show that regardless of the bulky groups at $\mathrm{C} 2$ and $\mathrm{N} 3$ on the thiazolidinone ring, it is clear that in the solid state the preferred conformation for efficient packing requires that the group at $\mathrm{C} 2$ be in a pseudo axial position. In this instance with a cyclohexyl ring attached to N3 of the thiazolidinone ring, the cyclohexyl ring orients itself with the thiazolidinone ring in an equatorial position from the cyclohexyl carbon to the N3 thiazolidinone nitrogen, and the proton on that cyclohexyl carbon is axial and points away from the thiazolidinone ring. In addition, the cyclohexyl ring is orthogonal to the thiazolidinone ring and points towards the carbonyl group of the thiazolidinone ring.

When the solution conformation for 3-cyclohexyl-2-phenyl-1,3-thiazolidin-4-one is considered from the perspective of the ${ }^{1} \mathrm{H} \mathrm{NMR}$ in $\mathrm{CDCl}_{3}$, the preferred conformation appears to be B (Figure 2) or 7a (Figure 7). The molecular modeling studies best emulate the solution state, and calculations at the MP2 level indicate that there could be equilibration between two thiazolidinone conformers $7 \mathrm{a}$ and $7 \mathrm{~d}$ (Figure 7), with 7a being the global minimum of the two, more stable by $5.69 \mathrm{kcal} / \mathrm{mol}$. It should be noted that in these two conformations the thiazolidinone ring is orthogonal to the cyclohexyl ring in both instances, one equatorial at the cyclohexyl $\mathrm{C} 1,7 \mathrm{a}$ (and equivalent to 5a) and the other axial, $7 \mathrm{~d}$, (and equivalent to 5d). In the case of the equatorial cyclohexyl conformer the sulfur in the thiazolidinone ring is puckered down and in the axial cyclohexyl conformer the sulfur is puckered up. In both these configurations one would see the same methine proton at $\mathrm{C} 2$ coupling to the downfield methylene proton at $\mathrm{C} 5$ shown in Figure 6. The proton on $\mathrm{C} 1$ of the cyclohexyl ring appears as a multiplet at $3.9 \mathrm{ppm}$, consistent with expectations for a flipping ring on the NMR time scale (Figure 6). It should be noted that in the cyclohexyl equatorial conformer, the cyclohexyl ring moves into closer proximity to the phenyl group, and when it flips into the axial conformation it moves away from the phenyl ring but closer to the carbonyl group. We are currently using theory to further probe more energetic details of these possible conformational changes, and their commensurate energy barriers, and these results will be reported in the future.

As mentioned previously, one of the goals of this study was to measureelectronic effects of substituents in the phenyl ring at sites in the thiazolidinone ring at $\mathrm{C} 2, \mathrm{C} 4$ and $\mathrm{C} 5$ utilizing ${ }^{13} \mathrm{C}$ NMR data. No discernible correlations were observed using Hammett or Swain Lupton Dual Substituent Parameter constants for C4 or C5. However, a weak Hammett correlation was noted if the $p$-methoxy and $m$-nitro substituents were removed from consideration. The meta-nitro substituted compounds in Series 1-6 (Figure 1) have well documented deviations. 
This is the first case where a $p$-methoxy substituted molecule has shown a marked deviation, and appears to be due to the reasons addressed by Johnson (Johnson, 1978). Uniformly improved correlations have been observed in previous studies when only the para-substituted molecules are considered, and this included the $p$-methoxy group (Woolston et al., 1992; Tierney, Houghton, et al., 1996; Tierney, Sheridan, et al., 1996; Tierney et al, 2005; Tierney et al, 2008). It would appear that the weakness in the overall Hammett correlation at $\mathrm{C} 2$ and the lack of any noticeable correlation at $\mathrm{C} 4$ and $\mathrm{C} 5$ can possibly be accounted for by the lack of an aryl group at N3 which has been shown to attenuate conjugation from substituents to reaction site. Because of the presence of an alkyl over an aryl group at N3, our assumption that N3 is planar may also be incorrect as witnessed by the MP2 calculations. This slight pyramidalization of the nitrogen and the increased perturbations from the flipping of the cyclohexyl ring at N3 could possiblyexplain the decrease in sensitivity to the transmission of substituent effects from the $\mathrm{C} 2$ phenyl ring and the complete absence of transmission to $\mathrm{C} 4$ and $\mathrm{C} 5$.

\section{Experimental}

\subsection{General}

The thiazolidine-4-ones were prepared using the procedure previously described by adapting a method originally utilized by Surrey (Surrey, 1947). Melting points are uncorrected; a Uni-Melt capillary melting point apparatus was used. All spectra were recorded on a Bruker 400 at $298 \mathrm{~K}$ observing ${ }^{1} \mathrm{H}$ and ${ }^{13} \mathrm{C}$ at 400.13 and $100.61 \mathrm{MHz}$, respectively. All samples were dissolved in $\mathrm{CDCl}_{3}$ at a concentration of $50 \mathrm{mg} / \mathrm{mL}$ using precision bore $5 \mathrm{~mm}$ NMR tubes supplied by Norell, Inc.

${ }^{1} \mathrm{H}$ spectra were collected into $32 \mathrm{~K}$ data sets over a spectral width of $8012.8 \mathrm{~Hz}$ using a $30^{\circ}$ pulse; pulse width, $3.9 \mathrm{~ms}$; acquisition time, $4.09 \mathrm{~s}$; relaxation delay, $2.0 \mathrm{~s}$; number of scans, $128 .{ }^{13} \mathrm{C}$ spectra were collected into $16 \mathrm{~K}$ data sets over a spectral width of $25125 \mathrm{~Hz}$ with a $60^{\circ}$ observed pulse using Waltz-16 decoupling; pulse width, $19.9 \mathrm{~ms}$; acquisition time $1.304 \mathrm{~s}$; relaxation delay, $4.0 \mathrm{~s}$; number of scans, 2048. The spectrometer was locked to the deuterium resonance of the solvent $\left(\mathrm{CDCl}_{3}\right)$ and all chemical shifts were referenced to residual $\mathrm{CHCl}_{3}$. Infrared spectra were obtained as an evaporated thin film on a sodium chloride plate (Janos Technology, Inc) on a Nicolet Nexus 670 spectrometer using 32 scans at a $2 \mathrm{~cm}^{-1}$ resolution. Mass spectra were recorded on a Varian $2100 \mathrm{G}$ ion trap mass spectrometer, fitted with a Varian 3900 gas chromatograph: column-Factor 4 VF-5 $\mathrm{ms} 0.25 \mathrm{~mm}$ id, $30 \mathrm{~m}, 0.25 \mu \mathrm{m}$ film thickness, He carrier gas, $1.0 \mathrm{ml} / \mathrm{min}$ flow, $80{ }^{\circ} \mathrm{C}$ for 1 minute isothermal $15^{\circ} \mathrm{C} / \mathrm{min}$ to $275^{\circ} \mathrm{C}$ then $275^{\circ} \mathrm{C}$ for 3 minutes isothermal, injector temp $250{ }^{\circ} \mathrm{C}, 0 \mathrm{~min}, 1: 50$ split. Isolated yields are based on starting amounts for the imines (amine is the limiting reactant) and it was assumed that $100 \%$ of the imine was produced in situ. No attempt was made to maximize the product yields. Hammett and Swain-Lupton correlations were obtained using Excel in Microsoft Office.

The X-ray crystallographic analysis was obtained from a colorless block shaped crystal of formula $\mathrm{C}_{15} \mathrm{H}_{19} \mathrm{NOS}$ with approximate dimensions $0.08 \times 0.11 \times 0.18 \mathrm{~mm}$. The X-ray intensity data were measured at 298(2) K, on a Bruker SMART APEX CCD area detector system equipped with a graphite monochromator and a MoKa fine-focus sealed tube $(1=0.71073 \AA)$ operated at 1600 watts power $(50 \mathrm{kV}, 32 \mathrm{~mA})$. The detector was placed at a distance of $5.8 \mathrm{~cm}$ from the crystal.

A total of 1850 frames were collected with a scan width of $0.3^{\circ}$ in $w$ and an exposure time of 10 seconds/frame. The total data collection time was about 8 hours. The frames were integrated with the Bruker SAINT software package using a narrow-frame integration algorithm. The integration of the data using a Monoclinic unit cell yielded a total of 7520 reflections to a maximum q angle of $28.33^{\circ}$ ( $0.90 \AA$ resolution), of which 3744 were independent, completeness $=97.2 \%, \mathrm{R}_{\text {int }}=0.0217, \mathrm{R}_{\text {sig }}=0.0317$ and 2310 were greater than $2 \mathrm{~s}(\mathrm{I})$. The final cell constants: $\mathrm{a}=13.002(3) \AA, \mathrm{b}=10.044(2) \AA, \mathrm{c}=10.687(2) \AA, \mathrm{a}=90^{\circ}, \mathrm{b}=98.150(5)^{\circ}, \mathrm{g}=90^{\circ}$, volume $=$ $1381.5(5) \AA^{3}$, are based upon the refinement of the XYZ-centroids of 1554 reflections above $20 \mathrm{~s}(\mathrm{I})$ with $2.572^{\circ}$ $<\mathrm{q}<20.977^{\circ}$. Analysis of the data showed negligible decay during data collection. Data were corrected for absorption effects using the multiscan technique (SADABS). The ratio of minimum to maximum apparent transmission was 0.7970 .

The structure was solved and refined using the Bruker SHELXTL (Version 6.1) Software Package, using the space group P2(1)/c, with $Z=4$ for the formula unit, C15H19NOS. The final anisotropic full-matrix least-squares refinement on $\mathrm{F}^{2}$ with 163 variables converged at $\mathrm{R} 1=5.56 \%$, for the observed data and $\mathrm{wR} 2=$ $15.10 \%$ for all data. The goodness-of-fit was 1.033 . The largest peak on the final difference map was $0.386 \mathrm{e}^{-} / \AA^{3}$ and the largest hole was $-0.257 \mathrm{e}^{\mathrm{e} /} \AA^{3}$. Based on the final model, the calculated density of the crystal is 1.257 $\mathrm{g} / \mathrm{cm}^{3}$ and $\mathrm{F}(000)$ amounts to 560 electrons. 


\subsection{Synthesis and Characterization of Compounds}

3-cyclohexyl-2-(4-nitrophenyl)-1,3-thiazolidin-4-one (a) (60\%); m.p. 91-92 ${ }^{\circ} \mathrm{C} ; \mathrm{cm}^{-1} 1665.8(\mathrm{C}=\mathrm{O}) ;{ }^{1} \mathrm{H}$ NMR $\left(\mathrm{CDCl}_{3}\right)$ : 8.17-7.23 (4H, m, aromatics), $5.66(1 \mathrm{H}, \mathrm{d}, \mathrm{C} 2, \mathrm{~J}=1.6 \mathrm{~Hz}), 3.83(1 \mathrm{H}, \mathrm{dd}, \mathrm{C} 5, \mathrm{~J}=1.6 \mathrm{~Hz}$, and $\mathrm{J}=15.6 \mathrm{~Hz})$, $3.68(1 \mathrm{H}, \mathrm{m}, \mathrm{NCH}), 3.55(1 \mathrm{H}, \mathrm{d}, \mathrm{C} 5, \mathrm{~J}=15.6 \mathrm{~Hz}), 1.92-0.81(10 \mathrm{H}, \mathrm{m}$, cyclohexyls $) ;{ }^{13} \mathrm{C}$ NMR: $171.96(\mathrm{C} 4)$, $150.73,148.13,127.06,124.77,61.39$ (C2), 56.27, 33.15 (C5), 31.81, 30.48, 26.09, 25.46; (m/z) $306\left(\mathrm{M}^{+}\right)$, $\mathrm{C}_{15} \mathrm{H}_{18} \mathrm{~N}_{2} \mathrm{O}_{3} \mathrm{~S}(306.38)$.

3-cyclohexyl-2-(3-nitrophenyl)-1,3-thiazolidin-4-one (b) (64\%); oil; $\mathrm{cm}^{-1} 1665.4(\mathrm{C}=\mathrm{O}) ;{ }^{1} \mathrm{H}$ NMR $\left(\mathrm{CDCl}_{3}\right)$ : 8.13-7.41 (4H, m, aromatics), $5.66(1 \mathrm{H}, \mathrm{d}, \mathrm{C} 2, \mathrm{~J}=1.6 \mathrm{~Hz}), 3.85(1 \mathrm{H}, \mathrm{dd}, \mathrm{C} 5, \mathrm{~J}=2.0 \mathrm{~Hz}$, and J=15.6 Hz), $3.70(1 \mathrm{H}$, $\mathrm{m}, \mathrm{NCH}), 3.55(1 \mathrm{H}, \mathrm{d}, \mathrm{C} 5, \mathrm{~J}=15.6 \mathrm{~Hz}), 1.97-0.81(10 \mathrm{H}, \mathrm{m}$, cyclohexyls $) ;{ }^{13} \mathrm{C}$ NMR: $169.92(\mathrm{C} 4), 146.76$, $143.82,130.35,128.52,121.95,119.32,59.64(\mathrm{C} 2), 54.35,31.18(\mathrm{C} 5), 29.69,28.40,24.11,23.43 ;(\mathrm{m} / \mathrm{z}) 306\left(\mathrm{M}^{+}\right)$ $\mathrm{C}_{15} \mathrm{H}_{18} \mathrm{~N}_{2} \mathrm{O}_{3} \mathrm{~S}$ (306.38).

3-cyclohexyl-2-(4-fluorophenyl)-1,3-thiazolidin-4-one (c) (75\%); m.p. 87-89 ${ }^{\circ} \mathrm{C} ; \mathrm{cm}^{-1} 1655.0(\mathrm{C}=\mathrm{O}) ;{ }^{1} \mathrm{H}$ NMR $\left(\mathrm{CDCl}_{3}\right)$ : 7.23-6.95 $(4 \mathrm{H}, \mathrm{m}$, aromatics), $5.57(1 \mathrm{H}, \mathrm{d}, \mathrm{C} 2, \mathrm{~J}=1.6 \mathrm{~Hz}), 3.79(1 \mathrm{H}, \mathrm{dd}, \mathrm{C} 5, \mathrm{~J}=1.8 \mathrm{~Hz}$ and $\mathrm{J}=15.8 \mathrm{~Hz})$, $3.70(1 \mathrm{H}, \mathrm{m}, \mathrm{NCH}), 3.51(1 \mathrm{H}, \mathrm{d}, \mathrm{C} 5, \mathrm{~J}=15.6 \mathrm{~Hz}), 1.65-0.82(10 \mathrm{H}, \mathrm{m}$, cyclohexyls $) ;{ }^{13} \mathrm{C}$ NMR: $171.67(\mathrm{C} 4)$, 164.23, 161.76,138.94, 128.43, 116.23, 62.24 (C2), 56.33, 33.36 (C5), 31.24, 30.24, 26.21, 25.52; (m/z) 297 $\left(\mathrm{M}^{+}\right), \mathrm{C}_{15} \mathrm{H}_{18} \mathrm{NOSF}$ (297.37).

3-cyclohexyl-2-(3-fluorophenyl)-1,3-thiazolidin-4-one (d) (58\%); m.p. 101-2 ${ }^{\circ} \mathrm{C} ; \mathrm{cm}^{-1} 1669$ (C=O); ${ }^{1} \mathrm{H}$ NMR $\left(\mathrm{CDCl}_{3}\right)$ : 7.02-6.92 (4H, m, aromatics), $5.55(1 \mathrm{H}, \mathrm{d}, \mathrm{C} 2, \mathrm{~J}=1.5 \mathrm{~Hz}), 3.83(1 \mathrm{H}, \mathrm{dd}, \mathrm{C} 5, \mathrm{~J}=1.5 \mathrm{~Hz}$ and $\mathrm{J}=15.7 \mathrm{~Hz})$, $3.71(1 \mathrm{H}, \mathrm{m}, \mathrm{NCH}), 3.51(1 \mathrm{H}, \mathrm{d}, \mathrm{C} 5, \mathrm{~J}=15.5 \mathrm{~Hz}), 1.67-0.829(10 \mathrm{H}, \mathrm{m}$, cyclohexyls $) ;{ }^{13} \mathrm{C}$ NMR: $171.86(\mathrm{C} 4)$, 164.51, 162.05, 145.99,130.91, 121.92, 116.01, 113.37, 62.11 (C2), 56.31, 33.24 (C5), 31.35, 30.34, 26.18, 25.54; $(\mathrm{m} / \mathrm{z}) 297\left(\mathrm{M}^{+}\right), \mathrm{C}_{15} \mathrm{H}_{18} \mathrm{NOSF}(297.37)$.

2-(4-chlorophenyl)-3-cyclohexyl-1,3-thiazolidin-4-one (e) (44\%); m.p. 110-111 ${ }^{\circ} \mathrm{C} ; \mathrm{cm}^{-1} 1667.8(\mathrm{C}=\mathrm{O}) ;{ }^{1} \mathrm{H}$ NMR $\left(\mathrm{CDCl}_{3}\right)$ : 7.27-7.16 $(4 \mathrm{H}, \mathrm{m}$, aromatics), $5.55(1 \mathrm{H}, \mathrm{d}, \mathrm{C} 2, \mathrm{~J}=1.6 \mathrm{~Hz}), 3.80(1 \mathrm{H}, \mathrm{dd}, \mathrm{C} 5, \mathrm{~J}=1.8 \mathrm{~Hz}$ and $\mathrm{J}=15.4 \mathrm{~Hz}), 3.68(1 \mathrm{H}, \mathrm{m}, \mathrm{NCH}), 3.52(1 \mathrm{H}, \mathrm{d}, \mathrm{C} 5, \mathrm{~J}=15.6 \mathrm{~Hz}), 1.67-0.85(10 \mathrm{H}, \mathrm{m}$, cyclohexyls $) ;{ }^{13} \mathrm{C} \mathrm{NMR}:$ 171.83 (C4), 141.82, 134.78, 129.51, 127.88, 114.94, 62.15 (C2), 56.35, 33.62 (C5), 31.40, 30.33, 26.19, 25.53. $(\mathrm{m} / \mathrm{z}) 295\left(\mathrm{M}^{+}\right), \mathrm{C}_{15} \mathrm{H}_{18} \mathrm{NOSCl}(295.83)$.

2-(3-chlorophenyl)-3-cyclohexyl-1,3-thiazolidin-4-one (f) (41\%); m.p. 62-65 ${ }^{\circ} \mathrm{C}$; $\mathrm{cm}^{-1} 1660.7(\mathrm{C}=\mathrm{O})$; ${ }^{1} \mathrm{H}$ NMR $\left(\mathrm{CDCl}_{3}\right)$ : 7.24-7.11 (4H, m, aromatics), $5.52(1 \mathrm{H}, \mathrm{d}, \mathrm{C} 2, \mathrm{~J}=1.8 \mathrm{~Hz}), 3.82(1 \mathrm{H}, \mathrm{dd}, \mathrm{C} 5, \mathrm{~J}=1.8 \mathrm{~Hz}$ and $\mathrm{J}=15.4 \mathrm{~Hz})$, $3.76(1 \mathrm{H}, \mathrm{m}, \mathrm{NCH}), 3.52(1 \mathrm{H}, \mathrm{d}, \mathrm{C} 5, \mathrm{~J}=15.6 \mathrm{~Hz}), 1.67-0.87\left(10 \mathrm{H}, \mathrm{m}\right.$, cyclohexyl; ${ }^{13} \mathrm{C}$ NMR: $171.94(\mathrm{C} 4)$, $145.47,135.15,130.62,129.23,126.49,124.45,62.08$ (C2), 56.33, 33.27 (C5), 31.62, 30.46, 26.19, 25.54; (m/z) $295\left(\mathrm{M}^{+}\right), \mathrm{C}_{15} \mathrm{H}_{18} \mathrm{NOSCl}(295.83)$.

3-cyclohexyl-2-(4-bromophenyl)-1,3-thiazolidin-4-one (g) (67\%); m.p. 108-109 ${ }^{\circ} \mathrm{C} ; \mathrm{cm}^{-1} 1666.4(\mathrm{C}=\mathrm{O}) ;{ }^{1} \mathrm{H}$ $\operatorname{NMR}\left(\mathrm{CDCl}_{3}\right)$ : 7.43-7.10 (4H, m, aromatics), $5.53(1 \mathrm{H}, \mathrm{d}, \mathrm{C} 2, \mathrm{~J}=2.0 \mathrm{~Hz}), 3.80(1 \mathrm{H}, \mathrm{dd}, \mathrm{C} 5, \mathrm{~J}=1.8 \mathrm{~Hz}$ and J=15.4 $\mathrm{Hz}), 3.75(1 \mathrm{H}, \mathrm{m}, \mathrm{NCH}), 3.52(1 \mathrm{H}, \mathrm{d}, \mathrm{C} 5, \mathrm{~J}=15.6 \mathrm{~Hz}), 1.71-1.43\left(10 \mathrm{H}, \mathrm{m}\right.$, cyclohexyls); ${ }^{13} \mathrm{C}$ NMR: $171.84(\mathrm{C} 4)$, $142.37,132.45,128.44,129.90,62.19$ (C2), 58.35, 33.33 (C5), 31.44, 30.36, 26.19, 25.54; (m/z) $339\left(\mathrm{M}^{+}\right)$, $\mathrm{C}_{15} \mathrm{H}_{18} \mathrm{NOSBr}$ (340.28).

3-cyclohexyl-2-(3-bromophenyl)-3-1,3-thiazolidin-4-one (h) (45\%); oil; $\mathrm{cm}^{-1} 1664.4(\mathrm{C}=\mathrm{O}) ;{ }^{1} \mathrm{H}$ NMR $\left(\mathrm{CDCl}_{3}\right)$ : 7.42-7.15 (4H, m, aromatics), $5.52(1 \mathrm{H}, \mathrm{s}, \mathrm{C} 2), 3.81(1 \mathrm{H}, \mathrm{d}, \mathrm{C} 5, \mathrm{~J}=15.2 \mathrm{~Hz}), 3.75(1 \mathrm{H}, \mathrm{m}, \mathrm{NCH}), 3.51(1 \mathrm{H}, \mathrm{d}, \mathrm{C} 5$, $\mathrm{J}=15.2 \mathrm{~Hz}), 1.70-0.87$ (10H, m, cyclohexyls); ${ }^{13} \mathrm{C}$ NMR: $171.86(\mathrm{C} 4), 145.71,132.07,130.87,129.40,124.93$, 123.23, 61.99 (C2), 56.31, 32.26 (C5), 31.43, 30.37, 26.20, 25.54. (m/z) $339\left(\mathrm{M}^{+}\right), \mathrm{C}_{15} \mathrm{H}_{18} \mathrm{NOSBr}(340.28)$.

3-cyclohexyl-2-phenyl-1,3-thiazolidin-4-one (i) (64\%); m.p. 115-116 ${ }^{\circ} \mathrm{C}, \mathrm{cm}^{-1} 1658.6(\mathrm{C}=\mathrm{O}) ;{ }^{1} \mathrm{H}$ NMR $\left(\mathrm{CDCl}_{3}\right)$ : 7.47-7.36 (4H, m, aromatics), $5.74(1 \mathrm{H}, \mathrm{d}, \mathrm{C} 2, \mathrm{~J}=1.8 \mathrm{~Hz}), 3.99(1 \mathrm{H}, \mathrm{dd}, \mathrm{C} 5, \mathrm{~J}=1.8 \mathrm{~Hz}$ and $\mathrm{J}=15.2 \mathrm{~Hz}), 3.90(1 \mathrm{H}$, $\mathrm{m}, \mathrm{NCH}), 3.68(1 \mathrm{H}, \mathrm{d}, \mathrm{C} 5, \mathrm{~J}=15.2 \mathrm{~Hz}), 1.86-1.59(10 \mathrm{H}, \mathrm{m}$, cyclohexyls $) ;{ }^{13} \mathrm{C}$ NMR: $171.94(\mathrm{C} 4), 13.161$, $129.28,129.07,126.47,62.83(\mathrm{C} 2), 56.28,33.47(\mathrm{C} 5), 31.28,30.32,26.24,25.58 .(\mathrm{m} / \mathrm{z}) 261\left(\mathrm{M}^{+}\right), \mathrm{C}_{15} \mathrm{H}_{19} \mathrm{NOS}$ (261.38).

3-cyclohexyl-2-(4-methylphenyl)-1,3-thiazolidin-4-one (j) (42\%); m.p. 68-70 ${ }^{\circ} \mathrm{C} ; \mathrm{cm}^{-1} 1664.9(\mathrm{C}=\mathrm{O})$; ${ }^{1} \mathrm{H}$ NMR $\left(\mathrm{CDCl}_{3}\right)$ : 7.20-7.07 (4H, m, aromatics), $5.55(1 \mathrm{H}, \mathrm{d}, \mathrm{CH}, \mathrm{J}=1.6 \mathrm{~Hz}), 3.81(1 \mathrm{H}, \mathrm{dd}, \mathrm{C} 5, \mathrm{~J}=2.0 \mathrm{~Hz}$ and J=15.6 Hz), $3.70(1 \mathrm{H}, \mathrm{m}, \mathrm{NCH}), 3.50(1 \mathrm{H}, \mathrm{dd}, \mathrm{C} 5, \mathrm{~J}=15.6 \mathrm{~Hz}), 2.28\left(3 \mathrm{H}, \mathrm{s}, \mathrm{CH}_{3}\right), 1.67-0.81(10 \mathrm{H}, \mathrm{m}$, cyclohexyls $){ }^{13} \mathrm{C}$ NMR: 171.89 (C4), 140.12, 138.96, 129.93, 126.41, 62.78 (C2), 56.31, 33.47 (C5), 31.20, 30.29, 26.27, 25.59, 21.59; (m/z) $275\left(\mathrm{M}^{+}\right), \mathrm{C}_{16} \mathrm{H}_{21} \mathrm{NOS}(275.41)$.

3-cyclohexyl-2-(3-methylphenyl)-1,3-thiazolidin-4-one (k) (69\%); m.p. 64-68 ${ }^{\circ} \mathrm{C} ; \mathrm{cm}^{-1} 1666.8(\mathrm{C}=\mathrm{O}) ;{ }^{1} \mathrm{H}$ NMR $\left(\mathrm{CDCl}_{3}\right)$ : 7.22-7.07 (4H, m, aromatics), $5.59(1 \mathrm{H}, \mathrm{d}, \mathrm{C} 2, \mathrm{~J}=2.0 \mathrm{~Hz}), 3.88(1 \mathrm{H}, \mathrm{dd}, \mathrm{C} 5, \mathrm{~J}=1.8 \mathrm{~Hz}$ and J=15.4 Hz), $3.80(1 \mathrm{H}, \mathrm{m}, \mathrm{NCH}), 3.56(1 \mathrm{H}, \mathrm{d}, \mathrm{C} 5, \mathrm{~J}=15.2 \mathrm{~Hz}), 2.34\left(3 \mathrm{H}, \mathrm{s}, \mathrm{CH}_{3}\right), 1.76-0.94(10 \mathrm{H}, \mathrm{m}$, cyclohexyls $) .{ }^{13} \mathrm{C}$ NMR: 
171.99 (C4), 158.75, 141.17, 139.07, 129.82, 129.13, 126.94, 123.44, 62.74 (C2), 56.31, 33.46 (C5), 31.23, $30.33,26.23,25.57,21.85 ;(\mathrm{m} / \mathrm{z}) 275\left(\mathrm{M}^{+}\right), \mathrm{C}_{16} \mathrm{H}_{21} \operatorname{NOS}(275.41)$.

3-cyclohexyl-2-(4-methoxyphenyl)-3-1,3-thiazolidin-4-one (l) (43\%); oil; $\left.\mathrm{cm}^{-1} 1664.4 \mathrm{C}=\mathrm{O}\right) ;{ }^{1} \mathrm{H}$ NMR $\left(\mathrm{CDCl}_{3}\right)$ : 7.17-6.79 (4H, m, aromatics), $5.55(1 \mathrm{H}, \mathrm{d}, \mathrm{C} 2, \mathrm{~J}=2.0 \mathrm{~Hz}), 3.81(1 \mathrm{H}, \mathrm{dd}, \mathrm{C} 5, \mathrm{~J}=2.0 \mathrm{~Hz}$ and $\mathrm{J}=15.4 \mathrm{~Hz}), 3.70(1 \mathrm{H}$, tt, $\mathrm{NCH}), 3.52(1 \mathrm{H}, \mathrm{dd}, \mathrm{C} 5, \mathrm{~J}=15.6 \mathrm{~Hz}), 3.74\left(3 \mathrm{H}, \mathrm{s}, \mathrm{OCH}_{3}\right), 1.68-0.84(10 \mathrm{H}, \mathrm{m}$, cyclohexyls $) .{ }^{13} \mathrm{C}$ NMR: 171.82 (C4), 159.27, 133.94, 127.17, 113.63, 61.84 (C2), 55.42, 54.81, 32.65 (C5), 30.27, 29.33, 25.39, 24.67; $(\mathrm{m} / \mathrm{z}) 291\left(\mathrm{M}^{+}\right), \mathrm{C}_{16} \mathrm{H}_{21} \mathrm{NO}_{2} \mathrm{~S}(291.41)$.

3-cyclohexyl-2-(3-methoxyphenyl)-1,3-thiazolidin-4-one (m) (73\%); m.p. 100-101 ${ }^{\circ} \mathrm{C} ; \mathrm{cm}^{-1} 1666.4(\mathrm{C}=\mathrm{O}) ;{ }^{1} \mathrm{H}$ NMR $\left(\mathrm{CDCl}_{3}\right): 7.22-6.74(4 \mathrm{H}, \mathrm{m}$, aromatics), $5.53(1 \mathrm{H}, \mathrm{d}, \mathrm{C} 2, \mathrm{~J}=2.0 \mathrm{~Hz}), 3.82(1 \mathrm{H}, \mathrm{dd}, \mathrm{C} 5, \mathrm{~J}=2.0 \mathrm{~Hz}$ and $\mathrm{J}=15.6 \mathrm{~Hz}), 3.76\left(1 \mathrm{H}, \mathrm{tt}, \mathrm{NCH}, 3.50\left(1 \mathrm{H}, \mathrm{d}, \mathrm{CH}_{2}, \mathrm{~J}=16.0 \mathrm{~Hz}\right), 3.74\left(3 \mathrm{H}, \mathrm{s}, \mathrm{OCH}_{3}\right), 1.23-0.81(10 \mathrm{H}, \mathrm{m}\right.$, cyclohexyls). ${ }^{13} \mathrm{C}$ NMR: 172.00 (C4), 160.31, 144.82, 130.36, 118.62, 114.22, 112.06, 62.76 (C2), 56.34, 55.67, 32.43 (C5), 31.20, 30.31, 26.23, 24.57; (m/z) $291\left(\mathrm{M}^{+}\right), \mathrm{C}_{16} \mathrm{H}_{21} \mathrm{NO}_{2} \mathrm{~S}(291.41)$.

\section{Acknowledgements}

We would like to thank Dr. David Dalton and the Chemistry Department of Temple University for allowing us to run the NMR spectra on their Bruker 400 spectrometer. We would also like to thank Dr. Charles DeBrosse for assistance with interpretation of the ${ }^{1} \mathrm{H}$ NMR spectra. We would also like to thank Dr. Phil Sonnett for reviewing the conformational structures proposed in this paper. In addition we would like to thank Gail Wray and Matthew Bodek for assistance in formatting this document. Finally we would like to acknowledge that X-ray analysis was conducted in 'The Small Molecule Crystallographic Facility' at the Pennsylvania State University, University Park Campus. The facility was established using funds from an NSF Chemistry Research Instrumentation and Facilities grant CHE-0131112. The crystallographic data (excluding structure factors) for 3-cyclohexyl-2-phenyl-1,3-thiazolidin-4-one have been deposited with the Cambridge Crystallographic Data Centre and the compound been assigned the deposition number CCDC 882565.

\section{References}

Barreca, M. L., Chimirri, A., De Luca, L., Monforte, A.,Monforte, P., Rao, A., ... Witvrouw, M. (2001). Discovery of 2,3-diaryl-1,3 thiazolidin-4-ones as potent anti-HIV-1 agents. Bioorganic \& Medicinal Chemistry Letters, 11, 1793-1796. http://dx.doi.org/10.1016/S0960-894X(01)00304-3

Dunning, T. H. (1989). Gaussian basis sets for use in correlated molecular calculations. I. The atoms boron through neon and hydrogen. Journal of Chemical Physics, 90, 1007-1023. http://dx.doi.org/10.1063/1.456153

Hickel, D., Leger, J. M., Carpy, A., Vigorita, M. G., Chimirri, A., \& Grasso, S. (1983). Structure of 3-(2-Pyridyl)-2-(2-tolyl)-1,3-thiazolidin-4-one, $\mathrm{C}_{15} \mathrm{H}_{14} \mathrm{~N}_{2} \mathrm{OS}$. Acta Crystallographica Section C, 39, 240-6. http://dx.doi.org/10.1107/S0108270183004266

Johnson, C. D. (1978). Use of the tool of increasing electron demand in determination of the status of the Yukawa-Tsuno (YT) Equation. Journal of Organic Chemistry, 43, 1814-1815. http://dx.doi.org/10.1021/jo00403a043

Ravichandran, V., Mourya, V. K., Agrawal, R. K., \& Vishwadivyalala, H. S. G. (2008). Prediction of anti-HIV activity of 1,3-thiazolidin-4-ones: QSAR approach. Digest Journal of Nanomaterials and Biostructures, 3(1), 19-31. Retrieved from http://www.chalcogen.infim.ro/Ravi-Argr2-thiadiazinone-DJNB1.pdf

Schaftenaar, G., \& Noordik, J. H. (2000). Molden: a pre- and post-processing program for molecular and electronic structures. Journal of Computer-Aided Molecular Design, 14, 123-134. http://dx.doi.org/10.1023/A:1008193805436

Schmidt, M. W., Baldridge, K. K., Boatz, J. A., Elbert, S. T., Gordon, M. S., Jensen, J. J., ... Montgomery, J. A. (1993). General atomic and molecular electronic structure system. Journal of Computational Chemistry, 14, 1347-1363. http://dx.doi.org/10.1002/jcc.540141112

Smith, F. E., Hynes, R. C., Tierney, J., Zhang, Y. C., \& Eng, G. (1995). The synthesis, molecular and crystal structure of the 1:1 adduct of triphenyltin chloride with 2,3-diphenyl-thiazolidin-4-one. Canadian Journal of Chemistry, 73, 95-99. http://dx.doi.org/10.1139/v95-014

Surrey, A. R. (1947). The Preparation of 4-Thiazolidones by the reaction of thioglycolic acid with Schiff Bases. Journal of the American Chemical Society, 69(11), 2911. http://dx.doi.org/10.1021/ja01203a507

Tierney, J., Houghton, G., Sanford, K., Mascavage, L., McCoy, M., Findeisen, A., \& Kilburn, J. (1996). Effects 
and conformational analysis of some substituted 2,3-diphenyl-1,3-thiazolidin-4-ones. Magnetic Resonance in Chemistry, 34, 573-576. http://dx.doi.org/10.1002/(SICI)1097-458X(199608)34:8<573::AID-OMR928>3.0.CO;2-D

Tierney, J., Issac, R., Mascavage, L., McCoy, M., Findeisen, A., \& Kilburn, J. (1996). Synthesis, spectroscopic and structural properties of novel substituted 2-trichloromethyl-3-phenyl-1,3-thiazolidin-4-ones. Heterocyclic Communications, 2, 227-232. http://dx.doi.org/10.1515/HC.1996.2.3.227

Tierney, J., Koyfmann, V., Cannon, K., Mascavage, L. M., \& Lagalante, A. (2008). A second study-predicting the ${ }^{13} \mathrm{C}$ chemical shifts for a series of substituted-3-(4-methoxy-phenyl)-2-phenyl-1,3-thiazolidin-4-ones. Heterocyclic Communications, 14, 453-460. http://dx.doi.org/10.1515/HC.2008.14.6.453

Tierney, J., Mascavage, L. M., Sheridan, D., Gorbecheva, D., Ripp, M., \& Son, S. (2005). A preliminary study on predicting the ${ }^{13} \mathrm{C}$ chemical shifts for a series of disubstituted 2,3-diphenyl-1,3-thiazolidin-4-ones. Heterocyclic Communications, 11, 215-222. http://dx.doi.org/10.1515/HC.2005.11.3-4.215

Tierney, J., Sheridan, D., Kovalesky, K., Mascavage, L. M., Schneider, K., \& Sheely, C. (1996). Substituent effects for some substituted 3-benzyl-2-phenyl-1,3-thiazolidin-4-ones using ${ }^{1} \mathrm{H}$ and ${ }^{13} \mathrm{C}$ NMR. Heterocyclic Communications, 6, 105-111. http://dx.doi.org/10.1515/HC.2000.6.2.105

Vazzana, I., Terranova, E., Mattioli, F., \& Sparatore, F. (2004). Aromatic Schiff bases and 2,3-disubstituted-1,3-thiazolidin-4-one derivatives as anti-inflammatory agents. Arkivoc, 2004(5), 364-374. http://dx.doi.org/10.3998/ark.5550190.0005.531

Woolston, C. R. J., Lee, J. B., \& Swinbourne, F. J. (1993). Carbon-13 NMR investigation of some substituted 1,3-thiazolidin-4-ones. Magnetic Resonance in Chemistry, 31, 348-351. http://dx.doi.org/10.1002/mrc.1260310407

Woolston, C. R. J., Lee, J. B., Swinbourne, F. J., \& Thomas, W. A. (1992). Proton NMR investigation of some substituted 1,3-thiazolidin-4-ones. Magnetic Resonance in Chemistry, 30, 1075-1078. http://dx.doi.org/10.1002/mrc.1260301109

\section{Copyrights}

Copyright for this article is retained by the author(s), with first publication rights granted to the journal.

This is an open-access article distributed under the terms and conditions of the Creative Commons Attribution license (http://creativecommons.org/licenses/by/3.0/). 